\title{
空気〜水〜土骨格連成有限変形解析による 大規模河川堤防の浸透・地震時挙動の評価
}

\author{
吉川 高広 1 - 野田 利弘 $2 \cdot$ 加藤 健太 $^{3}$ \\ 小高 猛司 4 ・李 圭太 5 ・高稲 敏浩 6 \\ 1正会員 名古屋大学助教 大学院工学研究科（广464-8603 名古屋市千種区不老町） \\ E-mail:yoshikawa.takahiro@b.mbox.nagoya-u.ac.jp \\ 2フェロー会員 名古屋大学教授 減災連携研究センター \\ 3正会員 東京ガス 株式会社 \\ 4正会員 名城大学教授 理工学部社会基盤デザイン工学科 \\ 5 正会員 株式会社建設技術研究所 \\ 6正会員 一般社団法人 GEOASIA研究会
}

\begin{abstract}
本論文では, 空気〜水〜土骨格連成有限変形解析コードを用いて，実在する砂質土・粘性土互層地盤上 の大規模河川堤防の浸透・地震時挙動の評価を行った。まず，河川水位の差に注目した浸透と地震の複合 時の解析を実施し，河川水位が高いほど堤内地への被害が大きくなることを示した．次に，基礎地盤の砂 質土層が砅質土相当の透水性を有する場合を想定して, 非定常浸透と地震時の応答を解析した。非定常浸 透時には，砂質土層上部に難透水性の粘性土層があるために，河川から砂質土層に大量の水が供給されて， 河川水位上昇後 8 時間経過時点からパイピング破壊に繋がり得るヒービングが発生することを示した．地 震時には, 碩質土相当の透水性であれば地震中に間隙水の移動が十分に生じて, 難透水性の粘性土層で覆

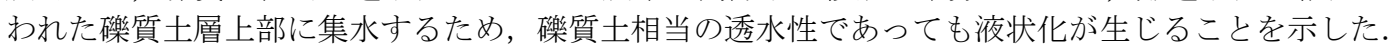

Key Words : dynamic analysis, finite deformation analysis, soil-water-air coupled analysis, river levee

\section{1. はじめに}

東日本大震災では，地盤の液状化や造成宅地・河川堤 防の崩壊等，甚大な被害が生じた．河川堤防の被害を例 にとると，これまで砂質土基礎地盤の液状化に焦点が当 てられてきたが，本震災では粘性土基礎地盤上の河川堤 防も崩壊した ${ }^{1,2), 3)}$. また地震被害だけでなく，2000年9 月の東海豪雨による新川堤防の被災や2012年7月の九州 北部豪雨による矢部川堤防の被災など，豪雨によって河 川が増水し，高水位が長時間継続したことで破堤する浸 透時の被害も多い，濃尾平野・関東平野・大阪平野には 海抜ゼロメートル地帯が広がっており，河川堤防が被害 を受けて浸水した場合には甚大な人的被害が発生すると 考えられる. 切迫する南海トラフ巨大地震や先鋭化する 集中豪雨を見据えると，河川堤防をはじめとした土構造 物の性能照査を適切かつ十分に行う必要がある.

一般に，土構造物の耐震照査を行うに当たっては，砂 質土のみを対象とした液状化解析を用い，浸透破壞を検 討するに当たっては，浸透解析と円弧すべり解析を組み
合わせた手法を用いることがほとんどである.これら動 的問題・破壊問題などに限定した専用解析コードを用い て, 東日本大震災で課題として挙げられた地震災害や, 近年先鋭化する集中豪雨災害，またこれら複合時の災害 等を事前予測できるとは言い難い.

以上の背景を踏まえ，著者らはこれまでに粘土から砂， さらにはその中間土までの広範な土の力学挙動を統一的 な枠組みで記述できる弾塑性構成式SYS カムクレイモデ ル4)搭載し, 飽和・不飽和両状態にある土に対して, 静的・動的の外力形態を問わず，変形から破壊までを一 貫した枠組で扱う空気〜水〜土骨格連成有限変形解析ב ード)を開発してきた。これは飽和土を対象とした同様 の解析コードのを不飽和土もシームレスに扱うことがで きるように拡張したものである. この解析コードを用い て, 本論文では実在する大規模河川堤防の地震時, 浸透 時および浸透・地震の複合時の照査を行う。具体的には, 東海地方に実在する砂質土・粘性土互層地盤上の河川堤 防の一断面を対象に，河川水位が高低異なる場合の耐震 照査およびパイピング破壊等の浸透破壊に対する照査を 


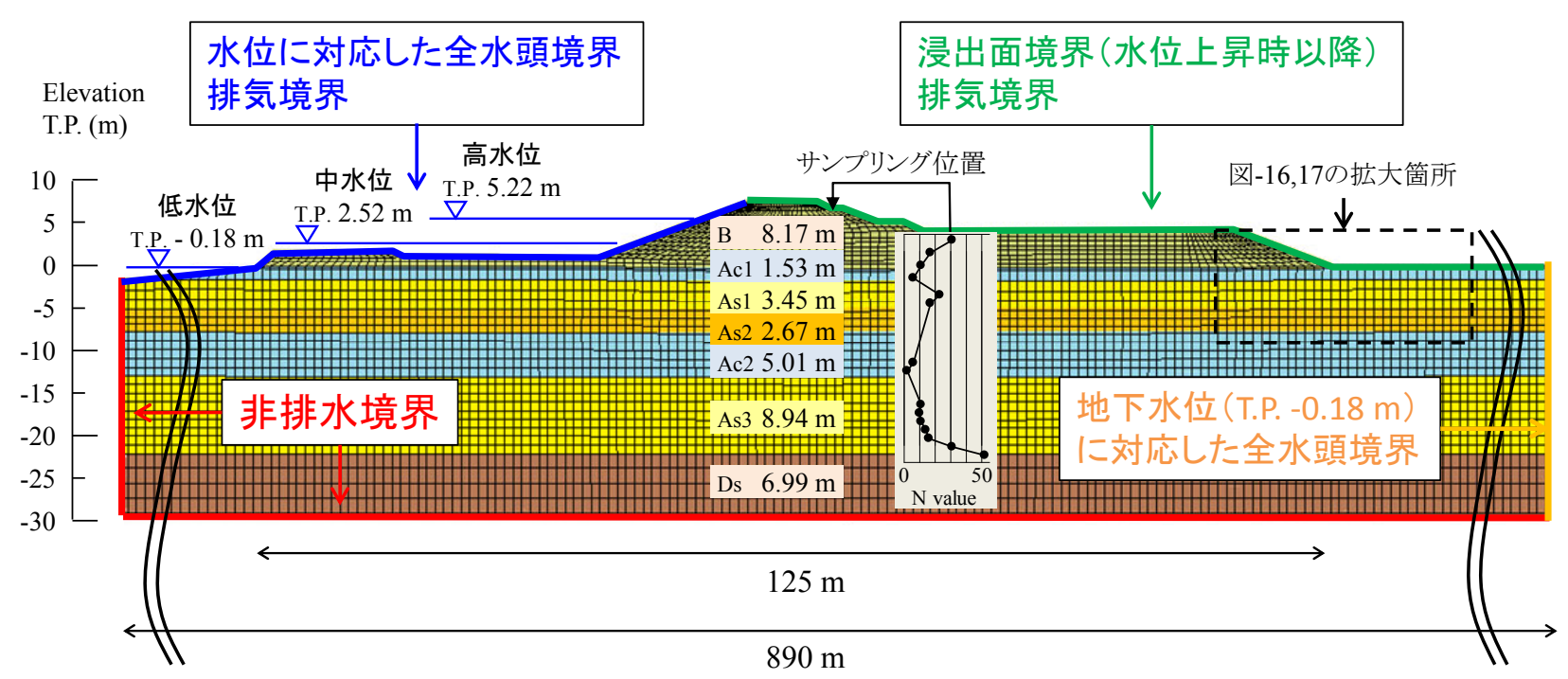

図-1 解析対象地点の地質横断図および境界条件（河道掘削・盛土構築後の解析断面）

表-1 土骨格の構成式に関する材料定数と初期值およびその他の物性值

\begin{tabular}{|c|c|c|c|c|c|c|c|}
\hline & $\mathrm{B}$ 層 & Ac1 層 & As1 層 & As2 層 & Ac2 層 & As3 層 & Ds 層 \\
\hline \multicolumn{8}{|l|}{ 弾塑性パラメータ } \\
\hline NCL の切片 N & 1.92 & 1.98 & 1.955 & 2.132 & 2.15 & 1.745 & 1.745 \\
\hline 限界状態定数 M & 1.25 & 1.4 & 1.2 & 1.3 & 1.4 & 1.35 & 1.35 \\
\hline 圧縮指数 $\tilde{\lambda}$ & 0.05 & 0.12 & 0.05 & 0.07 & 0.2 & 0.052 & 0.052 \\
\hline 膨潤指数 $\widetilde{\kappa}$ & 0.007 & 0.026 & 0.005 & 0.009 & 0.016 & 0.01 & 0.01 \\
\hline ポアソン比 v & 0.2 & 0.3 & 0.3 & 0.2 & 0.3 & 0.15 & 0.15 \\
\hline \multicolumn{8}{|l|}{ 発展則パラメータ } \\
\hline \multicolumn{8}{|l|}{ 構造劣化の塑性変形の } \\
\hline 進展尺度における & 1.0 & 0.5 & 0.9 & 0.6 & 0.3 & 1.0 & 1.0 \\
\hline \multicolumn{8}{|l|}{$-D_{\mathrm{v}}^{\mathrm{p}} と\left\|\boldsymbol{D}_{\mathrm{s}}^{\mathrm{p}}\right\|$ の割合 $c_{s}$} \\
\hline & 3.0 \\
\hline \multirow{2}{*}{\multicolumn{8}{|c|}{$\begin{array}{l}\text { 正規圧密土化指数 } m \\
\text { 回転硬化指数 } b\end{array}$}} \\
\hline & 2.0 & 0.05 & 3.5 & 1.5 & 0.25 & 3.5 & 3.5 \\
\hline \multicolumn{8}{|l|}{ 回転硬化限界面 $m_{b}$} \\
\hline \multicolumn{8}{|l|}{ 初期值 } \\
\hline 初期比体積 $\mathrm{v}_{0}$ & 1.86 & 1.962 & 1.885 & 2.059 & 2.113 & 1.665 & 1.50 \\
\hline 初期応力比 $K_{0}$ & 0.7 & 0.6 & 0.6 & 0.6 & 0.6 & 0.6 & 0.6 \\
\hline 初期構造の程度 $1 / R_{0}^{*}$ & 1.1 & 1.02 & 1.6 & 1.05 & 1.1 & 1.05 & 1.05 \\
\hline 初期異方性の程度 $K_{\beta}$ & 0.7 & 0.99 & 0.6 & 0.6 & 0.99 & 0.6 & 0.6 \\
\hline 土粒子密度 $\mathrm{g} / \mathrm{cm}^{3}$ & 2.634 & 2.650 & 2.650 & 2.650 & 2.650 & 2.650 & 2.650 \\
\hline 飽和透水係数 $\mathrm{m} / \mathrm{s}$ & $6.94 \times 10^{-7}$ & $6.28 \times 10^{-7}$ & $3.28 \times 10^{-5}$ & $3.28 \times 10^{-5}$ & $6.28 \times 10^{-7}$ & $5.00 \times 10^{-6}$ & $5.00 \times 10^{-6}$ \\
\hline
\end{tabular}

注） $D_{\mathrm{v}}^{\mathrm{p}}$ : 塑性ストレッチングの第1不変量, $\boldsymbol{D}_{\mathrm{s}}^{\mathrm{p}}$ ：偏差塑性ストレッチング， \|\| ：ノルムを意味する記号

表-2＼cjkstart盛土B層の不飽和に関係する材料定数および初期值

\begin{tabular}{c|c}
\hline 乾燥透気係数 $\mathrm{m} / \mathrm{s}$ & $3.82 \times 10^{-5}$ \\
最大飽和度 \% & 99.0 \\
最小飽和度 \% & 7.32 \\
van Genuchten パラメータ $\alpha \mathrm{kPa}^{-1}$ & 0.163 \\
van Genuchten パラメータ $n^{\prime}\left(m^{\prime}=1-1 / n^{\prime}\right)$ & 1.37 \\
初期飽和度 \% & 81.3 \\
\hline
\end{tabular}


実施して，そこから得られる防災・減災に関する知見を 示寸.

\section{2. 解析条件}

図-1は解析対象地点の地質横断図と境界条件を示寸. 本章の後半で述べる河道の掘削および盛土の構築過程を 経た，河川水位上昇前の解析断面である，基礎地盤は黄 色で示した砂質土（主に砂）層と水色で示した粘性土 （主に砂質シルト）層が互層状に堆積している．なお本 論文では，堤体盛土部分を $\mathrm{B}$ 層, 砂質土層は上部から As1 As3 層，粘性土層は上部からAc1層・Ac2層，基盤 をDs層と呼称する．参考として，土試料サンプリング 位置でのN值のデータも掲載した.

地下水位は原地盤の地表面と一致している（T.P.$0.18 \mathrm{~m} ）$ と仮定し，地盤は飽和状態，堤体は飽和・不飽 和の両状態を扱うこととする. 本解析で用いる土質パラ メーターは, 各層のサンプリング試料に対して実施した 圧密非排水三軸圧縮試験（CUB試験）および定ひずみ速 度圧密試験（CRS試験, 粘性土試料のみ）の結果を,

SYS カムクレイモデル4)で再現することで決定した．こ のとき原位置でのサンプリングから試験機にセットし， 試験を実施するまでの一連の流れを模擬して再現してい る》。また同一層の試料に対し，複数の試験が行われて いる場合には，全ての試験結果を同一の材料定数を用い， 初期状態のみを恋化させることで再現している. 図-2と 図-3は, 力学試験結果とSYS カムクレイモデル4にによる 再現結果の例として，B層とAc2層の場合をそれぞれ示 す. 地盤の飽和透水係数は過去に対象地点の近くで実施 されたボーリング孔を利用した現場透水試験の結果を用 いた. 表-1は各層の材料定数と初期值の一覧を示寸. な お，Ds層は深度が大きいためサンプリング自体が実施 されておらず，ボーリング調査のみ実施されている．ボ ーリングコア試料から砂主体の層であると判明したため, 直上のAs3層と同一の材料定数とした．初期状態はN值 が50以上と大きいことから, As3層よりも比体積を小さ くして, 密で硬い状態を表現した. 表-2はB層の不飽和 に関する材料定数と初期值を示寸. 図-4はB層の水分特 性曲線および透水係数・透気係数と飽和度の関係を示寸。 B層の保水性試験を実施していないため, 水分特性曲線 にはvan Genuchten式( $の$ Carsel and Parrish ${ }^{9} の$ のiltの值を用いた。 透水係数と透気係数の式にはMualemモデル10)適用した。 初期飽和度は，過去に対象地点の近くで実施された湿潤 密度試験結果の值を用いた。

次に解析断面の作製手順を示す．まず地下水位を地表 面に持つ水平成層地盤を作製する. 実地盤の初期状態は 不均質性を有し非常に複雑であるが，ここでは最単純な
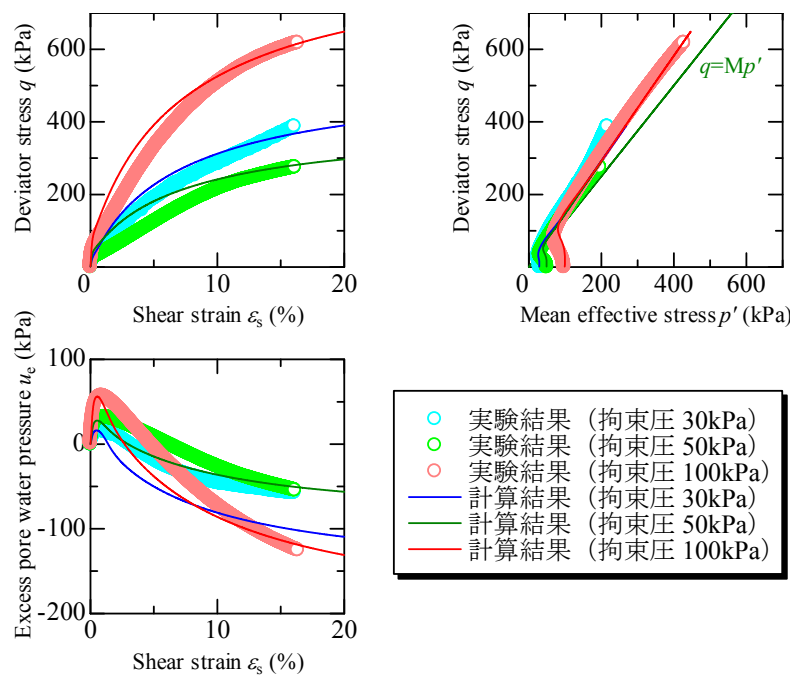

図-2 B層の力学試験結果と再現結果
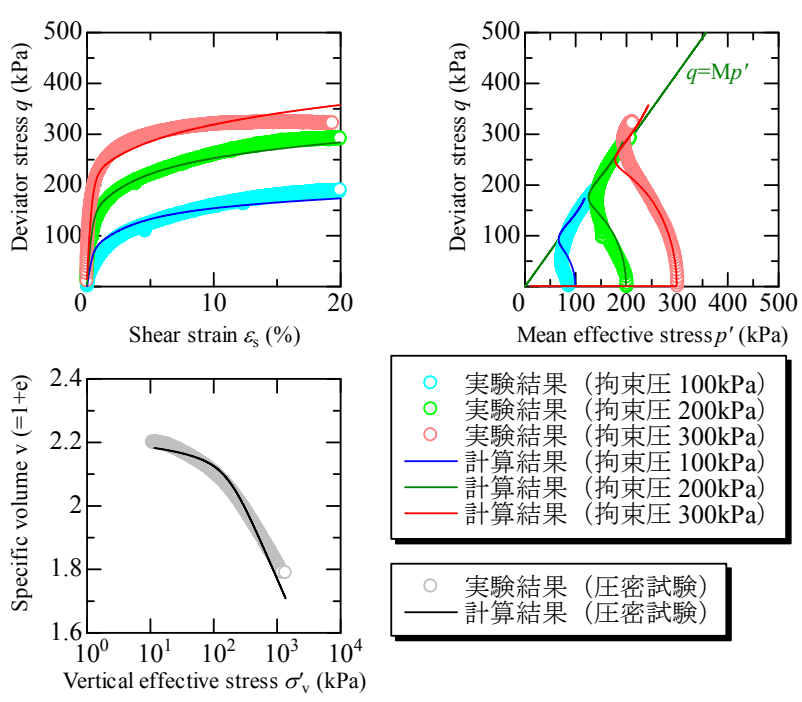

実験結果（圧密試験） 計算結果 (圧密試験)
図-3 Ac2層の力学試験結果と再現結果
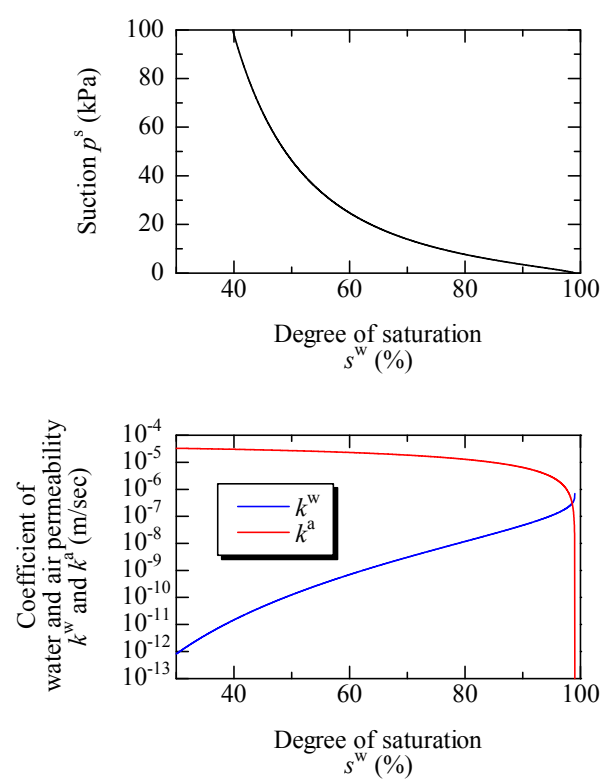

図-4 B 層の水分特性曲線および 透水係数・透気係数と飽和度の関係 
50 以下

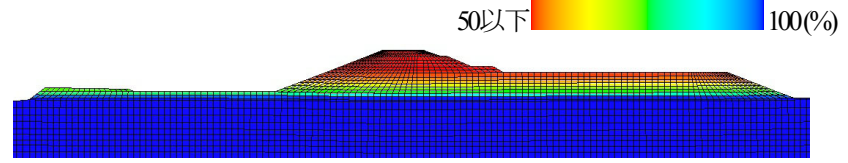

(a)低水位

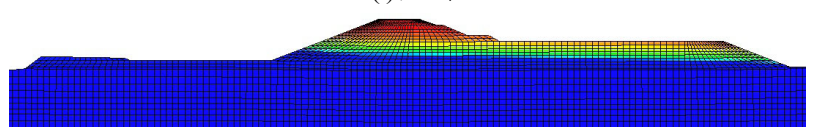

(b) 中水位

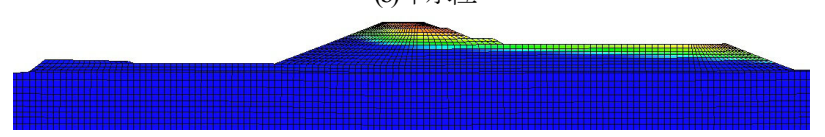

(c)高水位

図-5 地震前の堤体内の飽和度分布
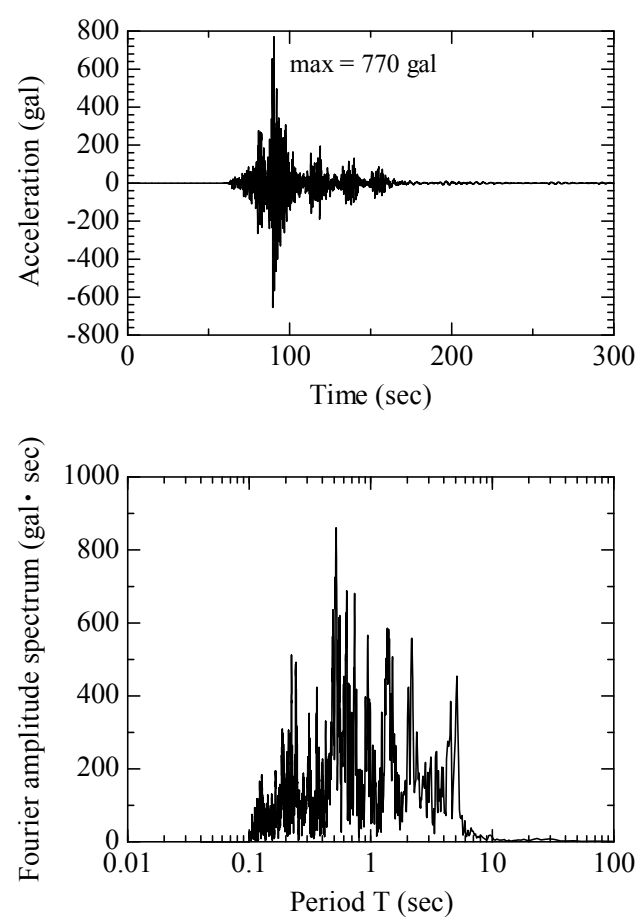

図-6 入力地震動とフーリエ振幅スペクトル

方法として, 比体積, 構造の程度, 応力比および異方性 の程度を各層で均一と仮定し, 過圧密比を土被り圧に応 じて鈆直方向に分布させた ${ }^{11)}{ }^{12}$. 水理境界条件は，地表 面および右端は地下水位に対応した全水頭一定境界とし， 下端および左端を非排水境界とする．解析対象は右岸堤 であり，実際は右岸堤と似た左岸堤が存在するため，両 者は同様の挙動をすると考えて, 左端での水のやり取り はないものとした.

作製した水平成層地盤に対して, 河道部分の掘削を行 う. 水中掘削のため, 土骨格の荷重のみを取り除き, 河 川水位は地下水位と一致させたままにする. 実際の河川 の成り立ちは極めて複雑であるが，ここでは河道形成を 応力の減少過程と考えて, 河川近くからサンプリングし た土試料の力学試験から決定した材料定数と初期值を持 つ地盤を掘削する方法を用いた. 河床に相当する土要素
の面には河川水位に対応した全水頭境界を設定する. そ の後, 3日で $1 \mathrm{~m}$ 盛土をする速さで50 cmずつ築堤した7). 堤防を築造する際には, 初期地盤作成時と同様に, 比体 積, 構造の程度, 応力比, 異方性の程度を各層で均一と し，過圧密比を土被り圧に応じて鉛直方向に分布させた 11), 12)、築堤後には過剩間隙水圧が消散するまで圧密計算 を行う。

圧密計算後, 河川水位を 1 秒当たり $0.3 \mathrm{~mm} の$ 定率で 5 時 間かけて計画高水位程度（T.P.+5.3m）まで上昇させ，定 常状態になるまで計算する.この上昇率は2000年 9 月 11 〜12日に発生した東海豪雨時に, 今回対象とした堤防の 観測所にて記録された河川水位の時刻歴から算出してい る. 河川水位の上昇に伴い, 川表側の河川水位より上の 要素では水理境界条件を地下水位に対応した全水頭一定 境界から浸出面境界に変更する。一方, 川董側も水が法 面から浸出することを考慮するために, 浸出面境界に変 更する．設定した河川水位は，水位を上昇させないで地 下水位と同じにした場合（低水位）と計画高水位（高水 位）およびその中間に位置する水位（中水位）の3ケー スである. 図-5は水位上昇後に定常状態を迎えたときの 各ケースの飽和度分布を示寸.

以上の過程を経た断面に対して地震応答解析を実施す る. 解析断面下端には密度 $\rho=2.0 \mathrm{~g} / \mathrm{cm}^{3}$, 世九断波速度 $\mathrm{Vs}$ $=300 \mathrm{~m} / \mathrm{s}$ の粘性境界 $\left.{ }^{13,},{ }^{14,}, 15\right)$, 左右両端の要素に側方境界 要素単純せん断変形境界淂を設定した。 せん断波速度は 現地で実施された電磁探査の結果から決定している.レ ベル2地震動として，2012年に内閣府南海トラフの巨大 地震モデル検討会にて策定された, 解析対象地点におけ る南海トラフ 5 連動地震の陸側ケースのNS成分を入力す る. 公開されている加速度データはVs $=700 \mathrm{~m} / \mathrm{s} の$ 解放基 盤のものであるため, $\mathrm{DYNEQ}^{177}$ を用いてVs $=300 \mathrm{~m} / \mathrm{s}$ の加 速度データを作成した. 図-6にこの地震動と，そのフー リエ振幅スペクトルを示す. 最大加速度が770galの巨大 な地震動であり, 周期が 0.5 秒程度の波が最も卓越して いるが，長周期から短周期まで幅広く含まれていること が特徴である. 図は省略するが，加速度の大きい57〜 200秒部分を抽出して求めた地震動と元々の地震動のフ ーリエ振幅スペクトルはほぼ等しいため, 本解析では計 算時間の短縮のために 57 200秒部分を抽出した地震動 を2E波として，下端のすべての節点に等しくE波を入力 した. 地震動入力後は下端の加速度の入力を止める以外 は全く同じ解析条件で，過剩間隙水圧が消散するまで地 震後の圧密計算を行った。

以上のように, 本解析は施工時から地震時までを対象 としているが, 土骨格の構成式は静的と動的のどちらに おいても同じものを用いている. パラメータは, 単調載 荷の三軸圧縮試験から決定しているが，後の図-20の土 要素の力学挙動が示すように, 繰り返し載荷時に平均有 
効応力がゼロ付近まで減少し液状化に向かう様子は表現 可能である. 今後は繰り返しせん断挙動をより適切に表 現可能な構成式による解析も実施していきたい.

\section{3. 河川水位の差が地震時挙動に与える影響}

各水位の地震直後のせん断ひずみ分布と平均骨格応力 18)分布をそれぞれ図-7と図-8に示す。ここにせん断ひず み $\varepsilon_{\mathrm{s}}$ は $, \varepsilon_{\mathrm{s}}=\sqrt{2 / 3\left(\boldsymbol{e}^{\prime} \cdot \boldsymbol{e}^{\prime}\right)}, \quad \boldsymbol{e}^{\prime}=\boldsymbol{e}-1 / 3(\operatorname{tr} \boldsymbol{e}) \boldsymbol{I}$, $\boldsymbol{e}=1 / 2\left(\boldsymbol{I}-\boldsymbol{B}^{-1}\right), \quad \boldsymbol{B}=\boldsymbol{F F}^{\mathrm{T}}$ であり, $\boldsymbol{I}$ は単位テンソ ル， $\boldsymbol{F}$ は土骨格の変形勾配テンソルを表す．図中に示 寸黒実線は層境を，黒破線は地震前の堤体および地表面 の形状を表す．まず，せん断ひずみ分布を見ると河川水 位の高低でひずみの生じ方が異なっている，低水位では 川表側（図の左側）のせん断ひずみが大きいが，高水位 では川裏側（図の右側）のせん断ひずみが大きい. 中水 位ではこれら二つの中間の変形が生じている.川表側に は河川水位に対応する静水圧を表面力として作用させて いて，水位が高いほど堤体は川裏側一押されるような状 態にある.このため, 高水位では川裏側, つまり堤内地 への変形が大きくなり，低水位では川表側への変形が大 きくなる. 次に平均骨格応力分布を見ると, 水位が高く なるにつれて堤体内の值が小さい. これは，図-5の飽和 度分布が示寸ように，水位が高いほど堤体内の飽和度が 高く, 瞬時に圧縮可能な空気が少ないためである. 地震 のような短時間の外力下では, 飽和度が高い土要素はほ ぼ定体積条件が満たされ，土骨格の塑性体積圧縮が弾性 体積膨張を引き起こし, 平均骨格応力が減少する. また 地盤の平均骨格応力に注目すると, 特にAs1層やAs2層 で大きく減少しており，堤体直下の土被り圧の大きい部 分を除いて液状化に向かっている.

図-9と図-10はそれぞれ地震中・地震後の左右法尻の 水平変位と天端中央の沈下量を示す，上述のように，河 川水位が高い方が川裏側の法尻の水平変位が大きく, 川 表側の水平変位が小さくなっている. また地震後に水平 変位が減少寸るが，これは堤体の沈下によって法尻が引 き込まれたためである．天端沈下量を見ると，いずれの ケースにおいても地震中に大きく沈下寸る. 河川水位の 違いで比較すると，水位が高い方が天端沈下量が小さい. 上述のように河川水位が高い場合は川裏側への変形が卓 越するが，川裏側に設けられた大きな段が抑え盛土とし て働き，川裏側の地盤の拘束圧を高めているため，高水 位の変形モードの方が沈下量が抑えられた.

低水位の地震直後の沈下量は $2.20 \mathrm{~m}$ であり, これは堤 防高の約27\%にあたる. 明治以降に発生した地震による 河川堤防の沈下量は堤防高の $75 \%$ 以内となっている ${ }^{19}$. 高水位では地震直後の沈下量は2.05mであり, このとき
堤防高はT.P.5.53mとなる. したがって地震後の堤防高が 河川水位を下回ることはないものの，ほぼ同程度まで沈 下寸るため越流する危険性がある.

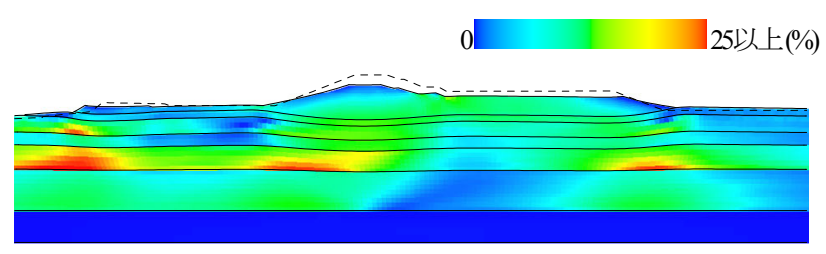

(a)低水位

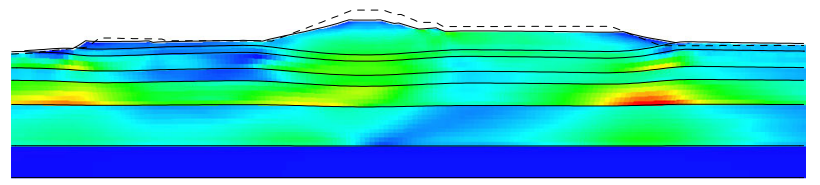

(b) 中水位

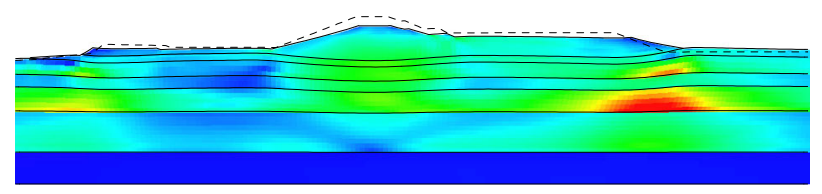

(c)高水位

図-7 地震直後のせん断ひずみ分布

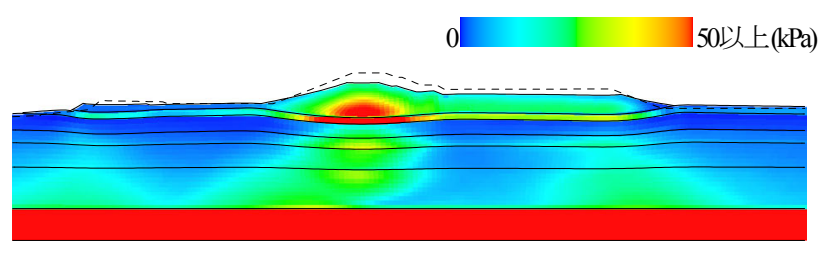

(a)低水位

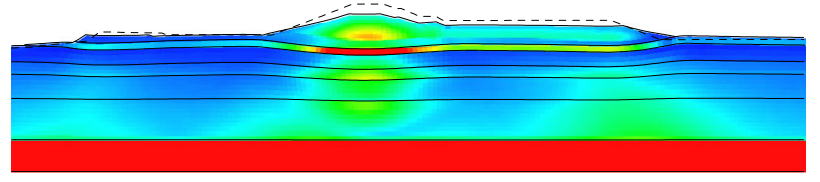

(b) 中水位

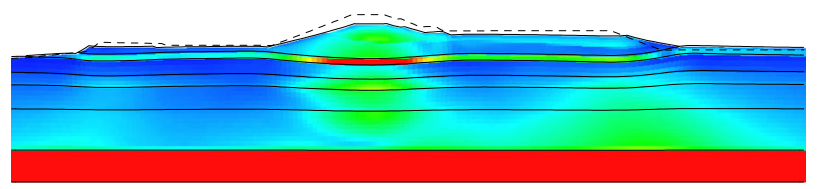

(c)高水位

図-8 地震直後の平均骨格応力分布

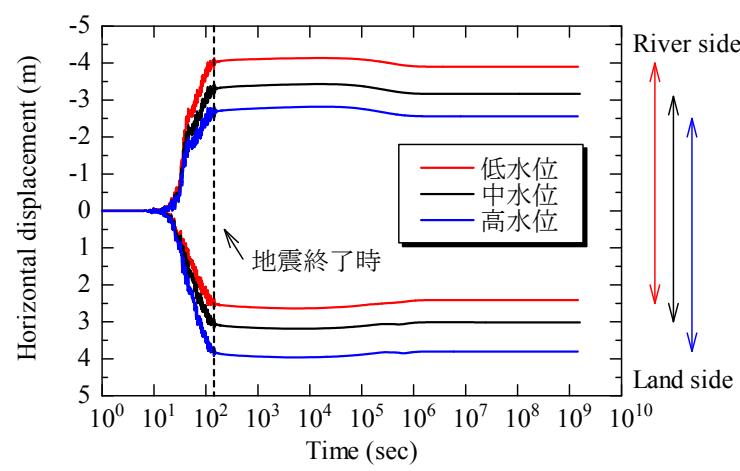

図-9 地震中 ・地震後の左右法尻の水平変位 


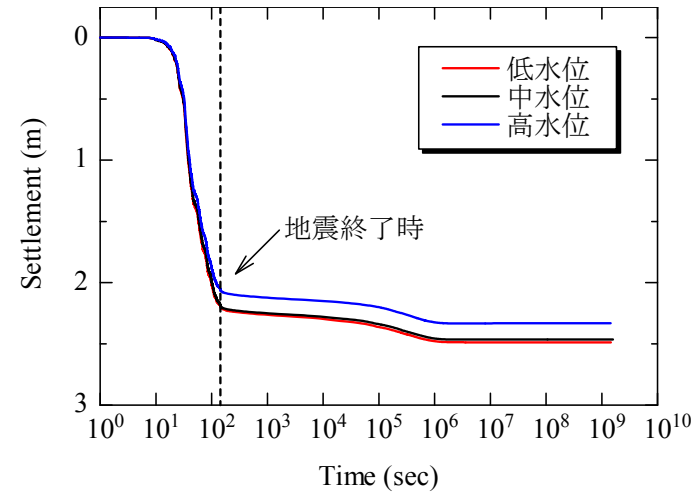

図-10＼cjkstart地震中・地震後の天端沈下量

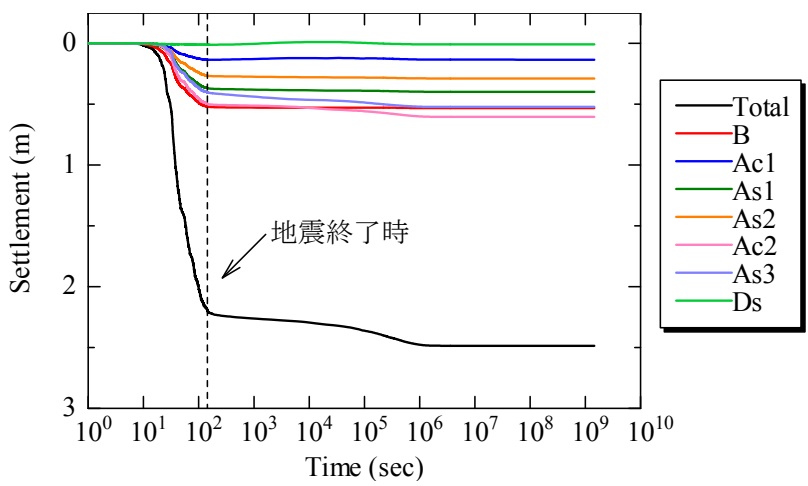

図-11 地震中・地震後の層別沈下量（低水位の場合）

図-11は低水位の場合の天端中央位置における層別沈 下量を示す. As1層，As2層，Ac1層およびAc2層でいず れも地震中に沈下が生じている。 これは，地震直後のせ ん断ひずみを表す図-7からわかるように，天端直下は各 層で同程度のひずみが生じている，天端直下はほぼ左右 対称の変形が生じているにもかかわらず，せん断ひずみ が生じているため, この分の一次元的な鉛直変形が生じ たことを示している．特に，As1層，As2層およびAc2層 については，図-8で示したように地震中に平均骨格応力 が著しく減少し剛性が低下したため，この沈下が生じた と言える.また，沈下時間関係にも注目すると，Ac2層 は地震後約 12 日間で $11 \mathrm{~cm}$ 程度沈下して, 最終層別沈下 量が最も大きい. 砂質土であるAs3層で地震後にも沈下 が生じる理由は，As3層直上に堆積するAc2層が過利間 隙水圧の消散を妨げたためであり，地震後約12日間で $12 \mathrm{~cm}$ 程度沈下する。ただし水位の違いによる層別沈下 量の差は小さかったため, 中水位と高水位の結果は省略 する.

また，高水位の場合が低水位の場合に比べて天端沈下 量が小さい解析結果に関して, 図-8の堤体内の平均骨格 応力は水位が高い方が小さく, 堤体内の飽和度も高いと いう観点からは，高水位の方が堤体が大きく変形し，沈 下量が大きく出ても良さそうである。ここで，図-2のB 層の側圧一定非排水三軸圧縮試験結果を見ると，堤体盛 土は非排水せん断時に塑性体積膨張し，負の過剰間隙水

圧が生じるほど締め固められた状態にあることがわかる. そのため, 図-8において高水位の方が平均骨格応力が小 さいとはいえ，ゼロ付近まで低下することはなかったと 言える. そこで，試しに堤体盛土構築時の初期間隙比を 0.86から1.0に大きくして，堤体が緩い場合の解析を行っ た. 図-12はB層が緩い場合の図-2に対応する土骨格の構 成式の応答を示す. 塑性体積膨張するものの, 負の過剰 間隙水圧は生じない状態にある。図-13と図-14は低水位 と高水位の場合の地震直後のせん断ひずみ分布と平均骨 格応力分布をそれぞれ示す．高水位の場合は堤体に大き なせん断ひずみが生じ，浸潤領域を中心に平均骨格応力 がゼロ付近まで低下している．図-15は堤体が緩い場合 の地震中・地震後の天端沈下量を示す. 比較のため, 図 -10に示した初期間隙比が0.86の場合の結果も掲載した. 堤体が緩い場合は高水位の方が天端沈下量が大きいこと がわかる.このように堤体盛土が緩い場合には，飽和度 が高い影響をより顕著に受け，低水位より高水位の方が 変形量が大きくなった.
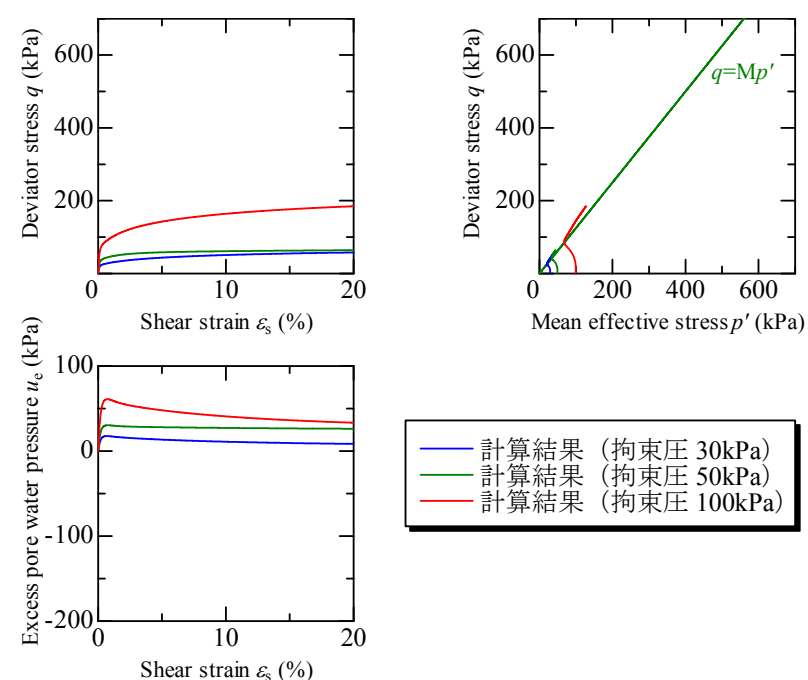

図-12Ｂ層が緩い場合の土骨格の構成式の応答

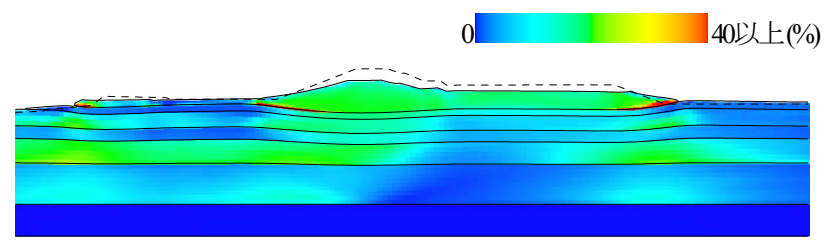

(a)低水位

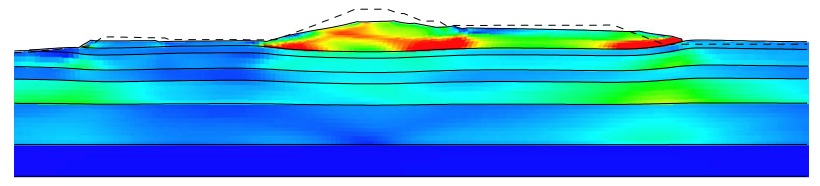

(b)高水位

図-13地震直後のせん断ひずみ分布（堤体が緩い場合） 


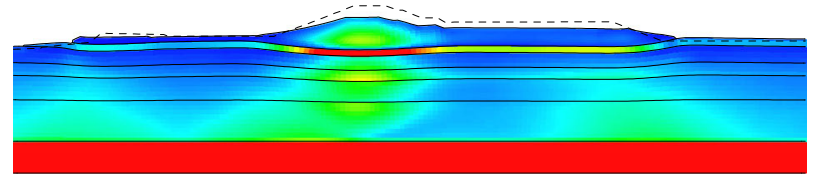

(a)低水位

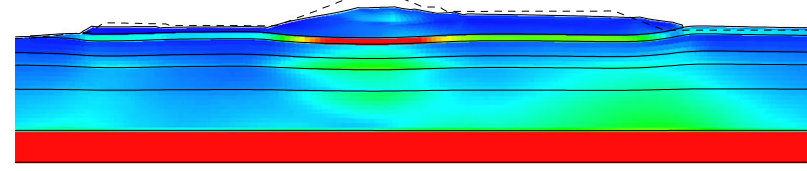

(b) 高水位

図-14 地震直後の平均骨格応力分布（堤体が緩、場合）

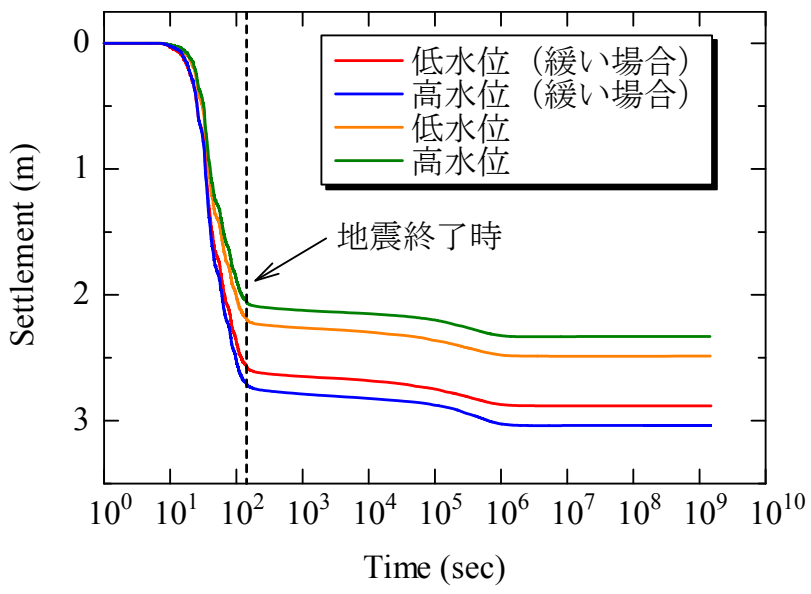

図-15 地震中・地震後の天端沈下量（堤体が緩、場合）

本解析コードは施工時から地震中・地震後までも連続 して同一の枠組みで計算可能であり, 本章では地震時, 特に地震中の変形を中心に示した. 地震後の変形は, 地 震中に比べて小さいため, 本論文では変形図は省略した

\section{4. 基礎地盤に碟質土を含む場合の浸透・地震時 挙動}

本解析断面の基礎地盤は最上部に粘性土層のAc1層が 堆積し，その下部に砂質土層のAs1層が存在しているた め，高水位時にはパイピング破壊の恐れがある。なお，

3.では高水位の場合に, 水位上昇過程から地震前の状態 までをシミュレートしたもののパイピング破壊に繋がる ような変形は生じなかった。しかし，基礎地盤は均質で はなく，同一層内であっても土質はばらつくことが考え られる，そこで本章では，As1層に碟質土が混入してい る場合を想定した非定常浸透および地震時の応答解析を 実施する．ここではAs1層の透水係数のみを100倍に変更 して, 砂質土相当の $3.28 \times 10^{-3}(\mathrm{~m} / \mathrm{sec})$ として解析を行った.
（1）礫質土相当の透水性を有する土と粘性土の互層地 盤上の河川堤防の非定常浸透時の応答

3. と同様に，有限要素メッシュを作製した後に河川水 位を計画高水位程度まで上昇させ，高水位状態を維持し た．図-16はせん断ひずみ，過剩間隙水圧，平均骨格応 力および間隙比変化の分布図の経時変化を，川裏法尻付 近を拡大して示寸（図-1に拡大箇所を明示した）。図中 に示寸太い黑実線は層境を示す，過剩間隙水圧は，設定 した地下水位（T.P.-0.18m）に対応寸る静水圧值から過 剰に発生した間隙水圧值と定義し，地下水位を位置水頭 の基準とした全水頭值と同義である．また，図の左下は 地層図を示す。

高水位状態が8時間経過すると，As1層の上部でせん断 ひずみが発生して体積澎張し始め，24時間経過時には地 盤が大きく膨れ，せん断ひずみが $20 \%$ 近くも生じている。 Ac1層の下部層で過剩間隙水圧が大きく発生し，せん断 ひずタが大きい箅所では平均骨格応力がほぼゼロまで咸 少している. 間隙比変化を見ると体積彭張する土要素が 現れ，この部分でせん断ひずみが生じている. As1層の 透水係数が非常に大きいため, 河川水位が上昇すると即 座にAs1層に水が供給されて間隙水圧が上昇し，難透水 層のAc1層との間に大きな動水勾配が生じる.しかし， As1層からAc1層への水の流出量よりも川からの供給量 が多いため，As1層の上部に水が溜まり，パイピング破 壊に繋がり得るヒービングが生じた.

\section{（2）パイピング破壊への対策工の検討}

パイピング破壊への対策として，堤内基盤排水工法に よる対策を講じた場合の効果について検証した. 具体的 にはウェルドレーン工法やリリーフウェル工法を想定し， 図-17の左下の地層図に示寸ように，Ac1層の一部を透水 性の良い材料に改良する. 本来ウェルドレーン工法はオ 一ルケーシング掘削機によって掘削し，その中に鉄筋か ごを組み立てた上でドレーン材（硯材）や間詰め材 （砂）を充填する ${ }^{20)}$. また，リリーフウェル工法は底に 砂利を敷いた最小径 $15 \mathrm{~cm}$ のスクリーンパイプを挿入し， 周辺にフィルター材を充填する ${ }^{21}$ が，本解析では簡単の ため, 飽和透水係数のみを変更して表現する. 改良部分 に用いた飽和透水係数はドレーン工設計マニュアル22)を 参考に $1.0 \times 10^{4}(\mathrm{~m} / \mathrm{sec})$ とした. 改良の範囲は多田羅ら ${ }^{20)}$ によるウェルドレーンの施工報告を参考に幅 $1 \mathrm{~m}$ とた. 図-17は堤内基盤排水工法を施した場合の，図-16 と同時 刻におけるせん断ひずみ，過剩間隙水圧，平均骨格応力 および間隙比変化の分布図を示す. As1層内の間隙水が 対策部分から地表面へと排出されるため，対策工無しの 場合と比較して過剰間隙水圧の上昇および平均骨格応力 の減少を抑えられている。 この後, 高河川水位が2日程 度継続してもヒービングは生じなかった。したがって, 
堤内基盤排水工法はパイピング破壊に対して一定の効果 が得られることがわかる. 河川堤防の浸透に対する照 査・設計のポイント ${ }^{23)}$ では堤内基盤排水工法は採用事例 が少なく，設計法が確立されていないとしており，今後， 今回のような解析の系統的実施により設計法が確立され ることが望まれる。

\section{（3）礫質土相当の透水性を有する土と粘性土の互層地 盤上の河川堤防の地震時の応答}

最後に, 碩質土相当の透水性を有する土と粘性土の互 層地盤上の河川堤防の地震時挙動を把握するため, パイ ピング破壊に繋がるようなヒービングが生じた本章(1) の場合に対して，地震応答解析を実施した，高水位状態 が4時間継続した場合についても地震応答解析を行った が，3.で述べた川裏側への変形が大きくなること以外に 河川水位の影響は見られなかったため, ここでは河川水
位は上昇させず，地下水位と同じT.P.-0.18mとした場合 について述べる. 3.と同様に下端はせん断波速度Vs= $300 \mathrm{~m} / \mathrm{s}$ の粘性境界 ${ }^{13), 14), 15)}$, 左右両端の要素に側方境界要 素単純せん断変形境界 ${ }^{10}$ を設定し，図-6に示した地震動 を入力する. 図-18は地震直後のせん断ひずみ分布を示 し，3.で示した低水位の場合の解析結果を比較として掲 載した。図-19は川裹側を拡大した図である。本節では， 3.の解析結果を「砂質土層」の場合，本章の結果を「礫 質土層」の場合と呼ぶこととする。図-18と図-19から砅 質土層上部で変形が大きいことがわかる.この現象の理 解のために, 図-20に最大加速度時の過唾間隙水圧およ び含水比変化の分布図を示した．摇れ始めからしばらく すると地盤がせん断を大きく受け，過剩間隙水圧が上昇 し，上向きに動水勾配が生じる．このとき，礫質土層は 透水係数が大きいため地震中においても間隙水の移動が 十分に生じ，地表面に向かって排水しようとする。しか

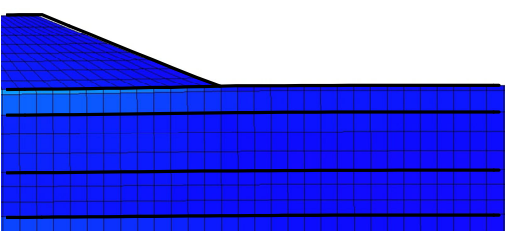

(i) 水位上昇直後

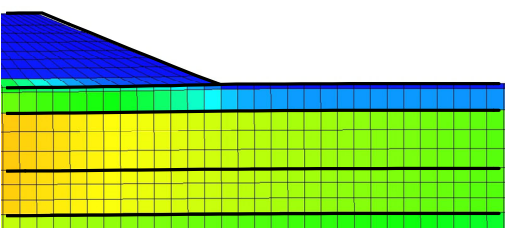

(i)水位上昇直後

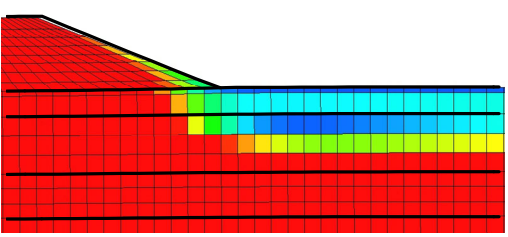

(i)水位上昇直後

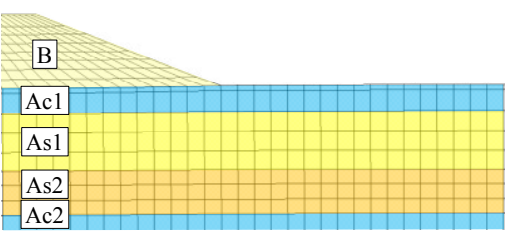

地層図

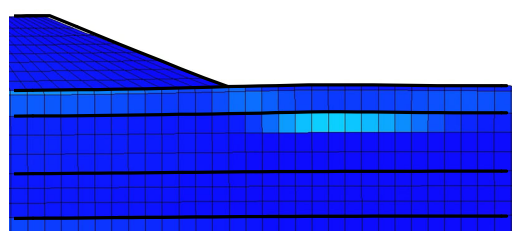

(ii)水位上昇後 8 時間経過時

(a)せん断ひずみ分布

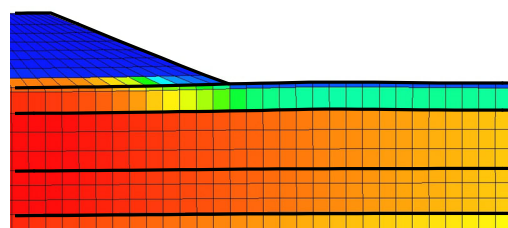

(ii)水位上昇後 8 時間経過時

(b)過剩間隙水圧分布

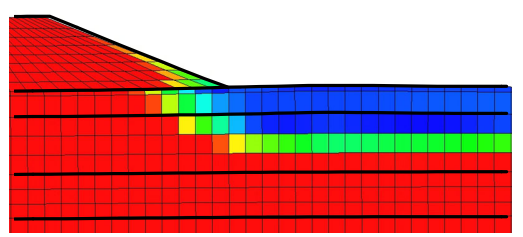

(ii)水位上昇後 8 時間経過時

(c)平均骨格応力分布

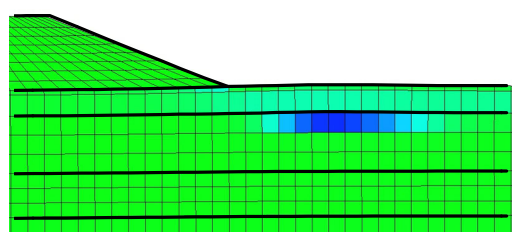

(ii)水位上昇後 8 時間経過時

(d)間隙比変化分布

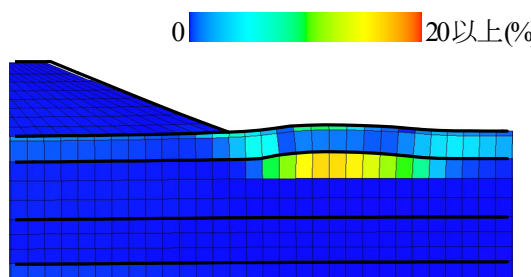

(iii)水位上昇後 24 時間経過時

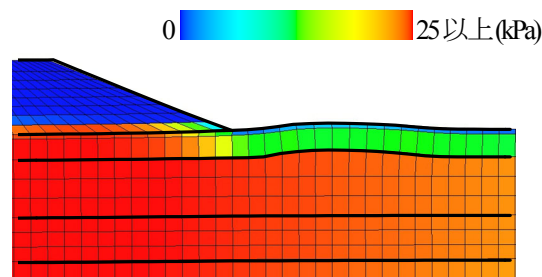

(iii)水位上昇後 24 時間経過時

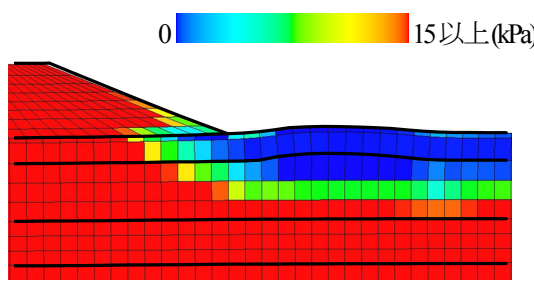

(iii)水位上昇後24時間経過時

-0.15以下国—上

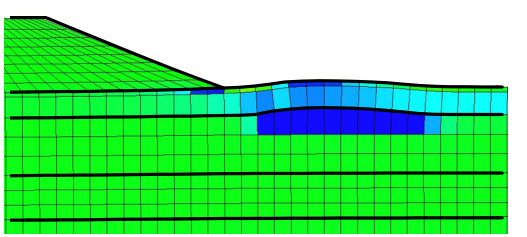

(iii)水位上昇後24時間経過時

図-16 パイピング破壊に繋がり得るヒービングが生じる非定常浸透時の解析結果 


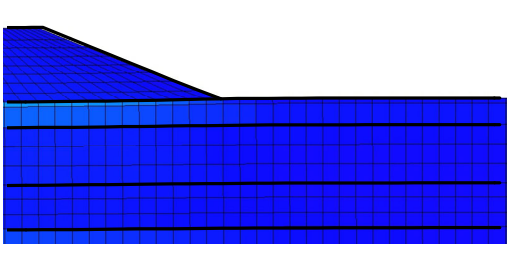

(i) 水位上昇直後

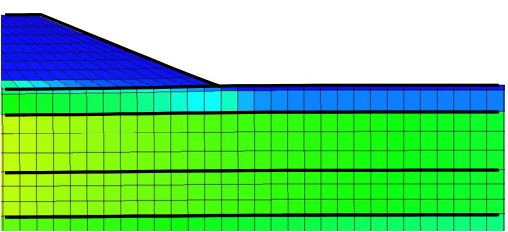

(i)水位上昇直後

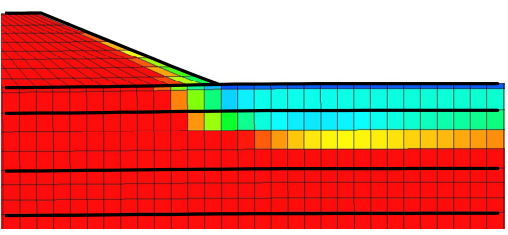

(i)水位上昇直後

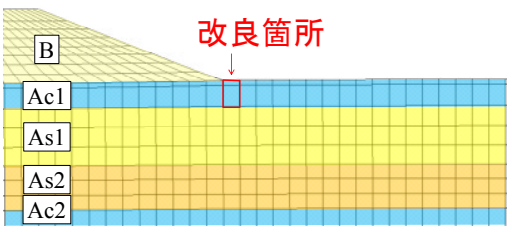

地層図

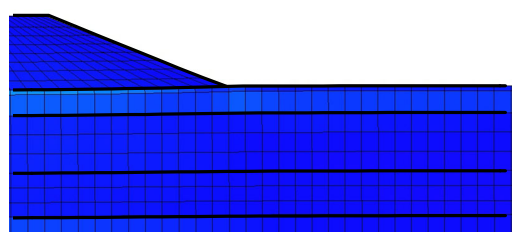

(ii)水位上昇後 8 時間経過時

(a)せん断ひずみ分布

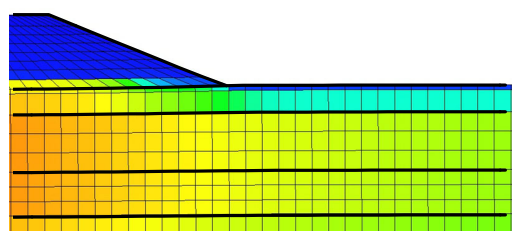

(ii)水位上昇後 8 時間経過時

(b)過剰間隙水圧分布

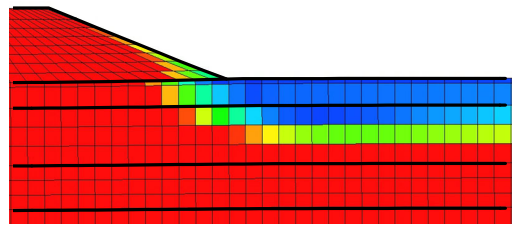

(ii)水位上昇後 8 時間経過時

(c)平均骨格応力分布

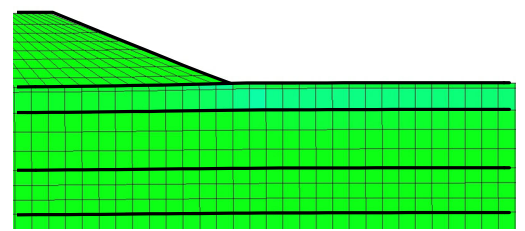

(ii) 水位上昇後 8 時間経過時

(d) 間隙比变化分布

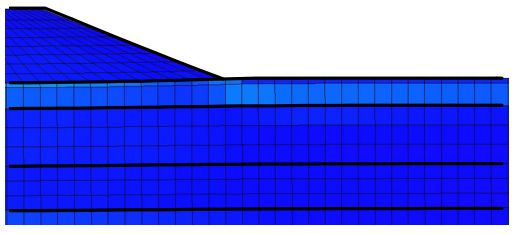

(iii)水位上昇後24時間経過時

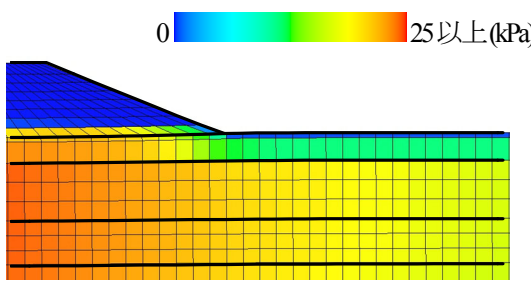

(iii)水位上昇後 24 時間経過時

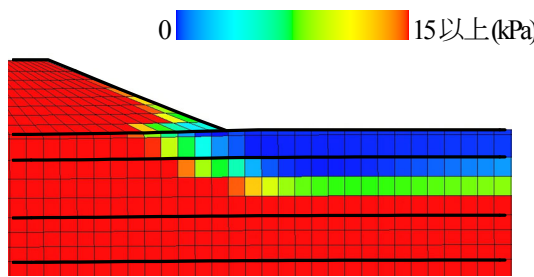

(iii)水位上昇後 24 時間経過時

-0.15 以下国—上

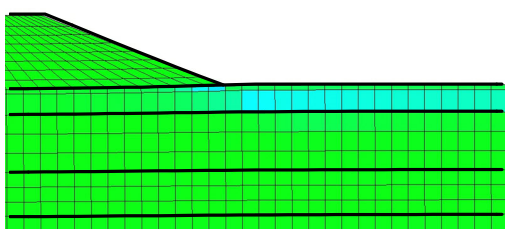

(iii)水位上昇後 24 時間経過時

図-17 パイピング破壊への対策工を施した場合の非定常浸透時の解析結果

し，礫質土層から地表面の間には透水性の悪いAc1層が 存在するため, 礫質土層上部に間隙水が溜まってしまう. このため碑質土層上部の平均骨格応力が低下し, 液状化 した状態になる．図-21は，図-19に示した礫質土層の縦 3要素の地震時の力学挙動を示す. 図中の白丸は地震開 始時点を示す．中央および下部の要素では排水して比体 積が減少しているのに対し, 上部の要素では吸水して比 体積が増加し, 液状化が発生している。一般に液状化は, 地震中の短時間では間隙水の移動が生じず，等体積条件 下でせん断されるため, 緩い砂で有効応力が減少して起 こる. 一方で透水性の良い䃋質土では非排水状態となら ないため液状化しにくいとされる．しかし，吉田 ${ }^{24}$ も指 摘はしているが，間隙水の排水方向に不透水層が存在す る場合には砂質土相当の透水性であっても液状化が生じ ることが示された．ただし，今回の解析では砂質土の透 水性のみを大きくし，礫質土の力学特性を考慮していな
いため，実際の礫質土の液状化を評価するためには更な る検討が必要である.

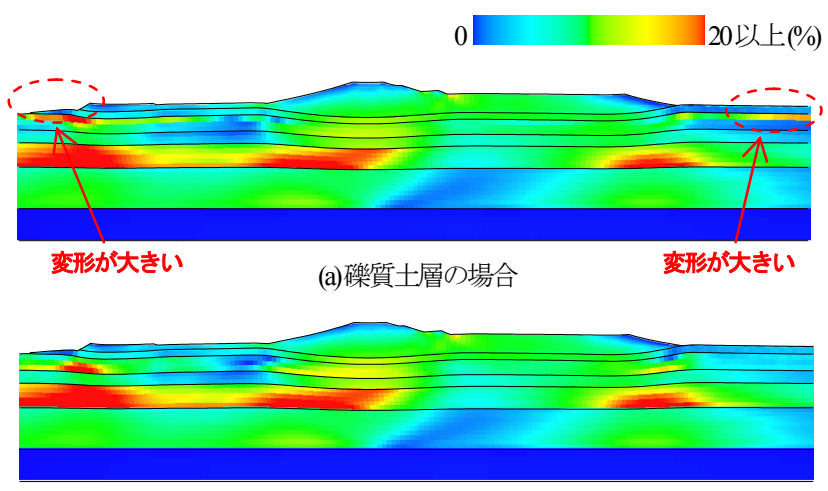

(b)砂質土層の場合

図-18＼cjkstart地震直後のせん断ひずみ分布の比較 


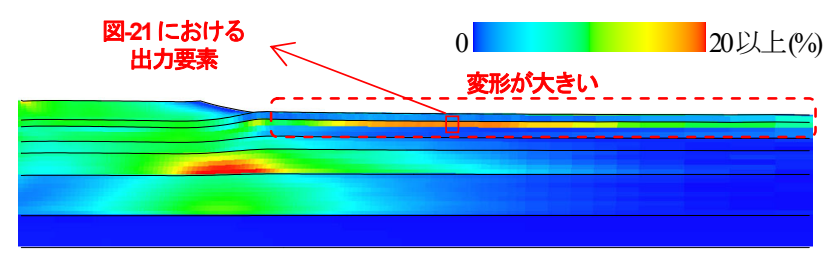

図-19地震直後の川裏側のせん断ひずみ分布（磎質土層）

0以下

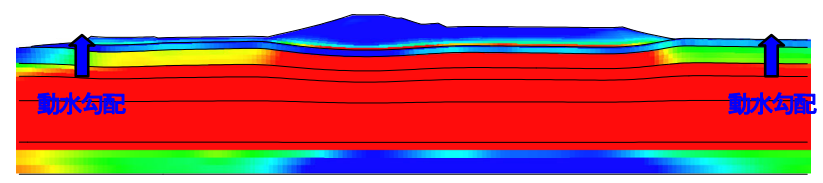

(a)過剩間隙水圧分布

-3以下

以上上(\%)

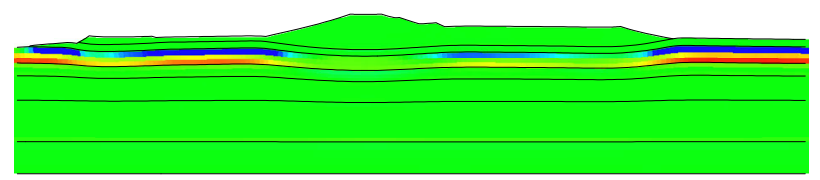

(b)含水比変化分布

図-20 最大加速度時の各種分布図（碩質土層）

\section{5. おわりに}

本論文では，弾塑性構成式 SYS カムクレイモデル ${ }^{4) を ~}$ 搭載した静的／動的空気〜水〜土骨格連成有限変形解析 コード 5)を用いて，東海地方に実在する砂質土・粘性土 互層地盤上の大規模河川堤防の浸透・地震時挙動の評価 を行った。 まず，河川水位の差に注目した浸透と地震の 複合時の解析を実施し，河川水位が高いほど堤内地一の 被害が大きくなることを示した．入力した地震動は南海 トラフ 5 連動地震で，地震中に天端が $2 \mathrm{~m}$ 以上沈下する
め，河川水位以下まで沈下はしないものの越流する危険 性があることを示した.ただし解析結果は，不均質性を 持つ地盤や盛土の単純化，河道生成過程の簡易化，地震 動の不確実性，解析モデルの適用範囲，2次元平面ひず み仮定等がある下で得られた量であることには注意する。 また，解析対象とした河川堤防は堤体盛土が良く締め固 められた状態にあったため，高水位の場合でも低水位・ 中水位の場合より大きな沈下は生じなかったが，堤体盛 土が緩い場合には，飽和度が高い影響を顕著に受け，低 水位より高水位の方が天端沈下量が大きくなった.

次に，基礎地盤の砂質土層が碟質土相当の透水性（透 水係数 $=3.28 \times 10^{-3} \mathrm{~m} / \mathrm{s}$ ) を有する場合を想定して, 非定 常浸透と地震応答時の解析を実施した. 非定常浸透時に は，河川水位上昇後8時間経過時点から，砂質土層上部 に難透水性の粘性土層が存在するために，礫質土層に大 量の水が供給されてパイピング破壊に繋がり得るヒービ ングが発生することを示した.また，このヒービングに 対して堤内基盤排水工法が有効であることも併せて示し た．地震時は，礫質土相当の透水性であれば，地震中で も間隙水の移動が十分に生じるため，粘性土層で覆われ た砅質土層上部に水が集まり液状化が生じる。これによ り地震時の被害が拡大する恐れがあることを示した。

以上のように，本解析コードは材料や外力形態を問わ ず変形・破壊照査が可能であり，広範な地盤防災・減災 に貢献するものと考える. 今後は，河川堤防の浸透破壊 に影響を与えるとされる細粒分の流出現象も視野に入れ た照査手法を構築していきたい，また，土骨格の構成式 に関して, 繰り返しせん断挙動をより適切に表現するた めの改良や不飽和土特有のサクション効果の導入, さら に水分特性曲線においては吸排水時のヒステリシス性や 間隙比の違いによる効果を導入して，より詳細な飽和・
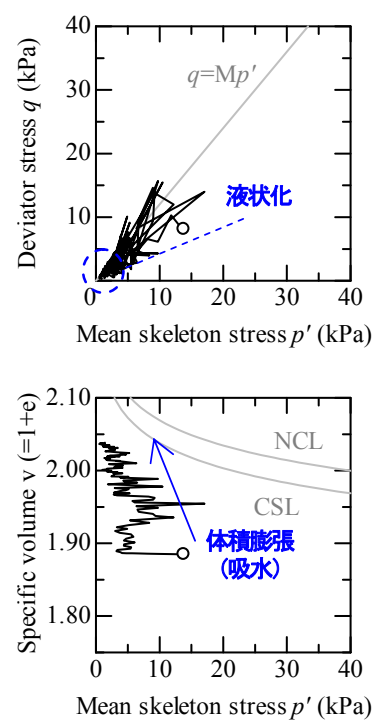

(a)上部の土要素の力学挙動
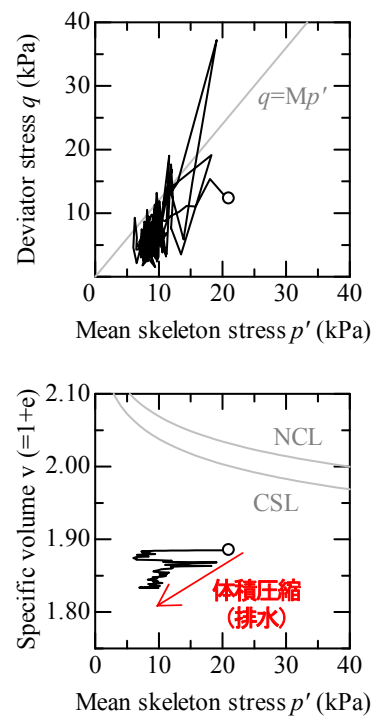

(b) 中央の土要素の力学挙動
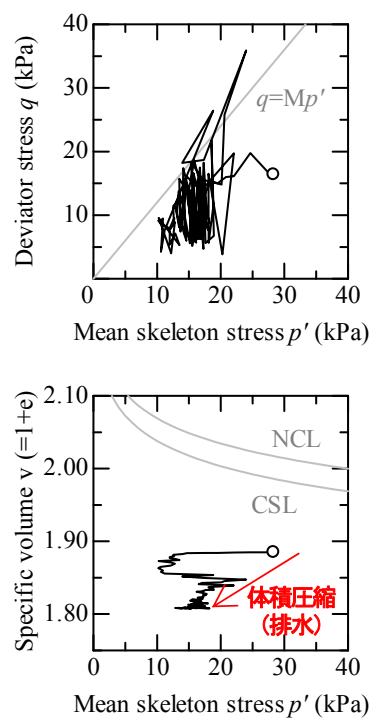

(c)下部の土要素の力学挙動

図-21 地震中の礫質土要素の力学挙動 
不飽和土の力学挙動を記述できる解析コードを構築予定 である。

謝辞：JSPS科研費25249064および国土交通省河川砂防技 術研究開発（H24年度～H26年度）の助成を受けた。

\section{参考文献}

1) 国土交通省東北地方整備局北上川等堤防復旧技術検 討会 : 北上川等堤防復旧技術検討会 報告書 本編, 2012.

$<$ http://www.thr.mlit.go.jp/Bumon/B00097/K00360/taiheiy ouokijishinn/kenntoukai/houkokusho.pdf>（2015/6/21 ア クセス)

2) 地盤工学会 : 地震時における地盤災害の課題と対策, 2011 年東日本大震災の教訓と提言（第二次）， 2012.

3) Sasaki Y., Towhata I., Miyamoto K., Shirato M., Narita A., Sasaki T. and Sako S.: Reconnaissance report on damage in and around river levees caused by the 2011 off the Pacific coast of Tohoku earthquake, Soils and Foundations, Vol.52, No.5, pp.1016-1032, 2012.

4) Asaoka, A., Noda, T., Yamada, E., Kaneda, K. and Nakano, M.: An elasto-plastic description of two distinct volume change mechanisms of soils, Soils and Foundations, Vol.42, No.5, pp.47-57, 2002.

5) Noda, T. and Yoshikawa, T.: Soil-water-air coupled finite deformation analysis based on a rate-type equation of motion incorporating the SYS Cam-clay model, Soils and Foundations, Vol.55, No.1, pp.45-62, 2015.

6) Noda, T., Asaoka, A. and Nakano, M.: Soil-water coupled finite deformation analysis based on a rate-type equation of motion incorporating the SYS Cam-clay model, Soils and Foundations, Vol.48, No.6, pp.771-790, 2008.

7) Takaine, T., Tashiro, M., Shiina, T., Noda, T. and Asaoka, A.: Predictive simulation of deformation and failure of peat-calcareous soil layered ground due to multistage test embankment loading, Soils and Foundations, Vol.50, No.2, pp.245-260, 2010.

8) van Genuchten, M. T.: A closed-form equation for predicting the hydraulic conductivity of unsaturated soils, Soil Science Society of America Journal, Vol.44, No.5, pp.892898, 1980.

9) Carsel, R.F. and Parrish, R.S.: Developing joint probability distribution of soil water retention characteristics, Water Resources Research, Vol.24, No.5, pp.755-769, 1988.

10) Mualem, Y.: A new model for predicting the hydraulic conductivity of unsaturated porous media, Water Resources Research, Vol.12, No.3, pp.513-522, 1976.

11) Noda, T., Asaoka, A. and Yamada, S.: Some bearing capacity characteristics of a structured naturally deposited clay soil, Soils and Foundations, Vol.47, No.2, pp.285-301, 2007.

12) Nakano, M., Yamada, E. and Noda, T.: Ground improvement of intermediate reclaimed land by compaction through cavity expansion of sand piles, Soils and Foundations, Vol.48, No.5, pp.653-671, 2008.

13) Lysmer, J. and R.L. Kuhlemeyer: Finite dynamic model for infinite media, $\operatorname{ASCE}(E M)$, Vol.95, No.4, pp.859-878, 1969.
14) Joyner, W.B. and Chen, A.T.F.: Calculation of nonlinear ground response in earthquakes, Bulletin of the Seismological Society of America, Vol.65, No.5, pp.1315-1336, 1975.

15) Noda, T., Takeuchi, H., Nakai, K. and Asaoka, A.: Coseismic and post-seismic behavior of an alternately layered sand-clay ground and embankment system accompanied by soil disturbance, Soils and Foundations, Vol.49, No.5, pp.739-756, 2009

16）吉見吉昭, 福武毅芳：地盤液状化の物理と評価 - 対 策技術，技報堂出版，344pp，2005.

17) Yoshida, N., Kobayashi, S., Suetomi, I. and Miura, K.: Equivalent linear method considering frequency dependent characteristics of stiffness and damping, Soil Dynamics and Earthquake Engineering, Vol.22, No.3, pp.205-222, 2002.

18) Jommi, C.: Remarks on the constitutive modelling of unsaturated soils, Experimental Evidence and Theoretical Approaches in Unsaturated Soils (eds. by Tarantino, A. and Mancuso, C.), Balkema, pp.139-153, 2000.

19) 地盤工学会 : 地盤 - 耐震工学入門, 丸善, $235 \mathrm{pp}$, 2008.

20) 多田羅謙治, 李圭太, 江川祐輔, 中土井佑輔 : 河川 堤防におけるウェルドレーン工法を用いた盤ぶくれ 対策に関寸る検討, 第 46 回(平成 25 年度) 研究発表 会論集，2013.

$<$ http://www.kk.jcca.or.jp/recital/pdf/119.pdf> (2015/6/21 アクセス)

21) 大根義男：実務者のための土質力学, 技法堂出版, $325 \mathrm{pp}, 2006$.

22）国土交通省水管理・国土保全局治水課：ドレーン工 設計マニュアル，2013.

$<$ http://www.mlit.go.jp/river/shishin_guideline/pdf/dorenk ou_manual.pdf> (2015/6/21アクセス)

23）独立行政法人土木研究所, 地質・地盤研究グループ 土質・振動チーム：河川堤防の浸透に対する照査・ 設計のポイント, 2013.

$<$ http://www.pwri.go.jp/team/smd/pdf/syousasekkei\%20po int1306.pdf>（2015/6/21 アクセス）

24) 吉田望：液状化に関する設計について考える，1995 年兵庫県南部地震 5 周年特別企画日本 地震 あれから これから, pp.81-84, 2000. 


\title{
EVALUATION OF MECHANICAL BEHAVIOR OF A LARGE RIVER LEVEE DURING SEEPAGE AND DURING/AFTER EARTHQUAKE BASED ON SOIL- WATER-AIR COUPLED FINITE DEFORMATION ANALYSIS
}

\author{
Takahiro YOSHIKAWA, Toshihiro NODA, Kenta KATO, \\ Takeshi KODAKA, KyuTae LEE and Toshihiro TAKAINE
}

In this study, seepage/seismic behavior of a large river levee on alternately layered ground of sandy and clayey soil was evaluated by a soil-water-air coupled finite deformation analysis code. The main findings are as follows: 1) Focusing on the river level, the analysis during seepage and during/after an earthquake was performed. The higher the river level, the larger the deformation in a direction toward the landside. 2) If the water permeability of the sandy soil layer is as high as "gravel", 8 hours after the river level rose, ground heaving which will lead to piping occurred near the landside toe. This is because the permeability of covering clayey soil layer is low and much water was supplied from the river to the sandy soil layer. 3) In the case of high permeability in the sandy soil layer as 2), during an earthquake, even when the river level is low, pore water is able to migrate in the sandy soil layer underlying clayey soil layer with low permeability. This results in liquefaction of the top of the sandy soil layer though the permeability is as high as gravel. 